\title{
'Judge \& Co.': Judicial Law-Making and the Mason Court
}

\author{
Geoffrey Lindell
}

$\mathbf{I}$

$\mathrm{T}$ has been said that 'judges were the traditional lawmakers' before 'they were overtaken by the onslaught of democratic theory and supplanted by parliament'. The onslaught followed in the wake of Jeremy Bentham's withering criticism of judges' role in the development of the law. Nevertheless, it is now widely accepted that judges still make law but in a special and more limited sense than the political branches of the government. Justice Michael Kirby (1983:59) has often reminded us of Lord Reid's (1972:22) famous remark that the declaratory theory of the common law is based on a 'fairy tale' which is no longer believed. So the issue, in Australia as in other parts of the world which apply Anglo-American common law principles, is not so much whether they make law, but in what sense, and in what circumstances.

The decisions of the Australian High Court during 1986-95, when Sir Anthony Mason presided as Chief Justice, saw dramatic changes to judge-made law. It was almost inevitable that decisions like the Mabo case would excite controversy about the legitimacy of the role of judges in making law. The recent publication of a book (Saunders, 1996) ${ }^{3}$ on the achievements of the Mason Court and the role of appellate courts of appeal in Australia and elsewhere makes it a timely occasion to revisit this debate.

\section{Areas of Change}

Among the Mason Court's most important constitutional decisions were those which established a constitutionally guaranteed freedom of political communication, the cases which concerned the separation of Commonwealth judicial power from legislative and executive power, and the Mabocase. Developments occurred in relation to

Geoffrey Lindell is Reader in Law at The University of Melbourne.

Sturgess and Chubb (1988:2-3), who referred to Jeremy Bentham's 1809 work Elements of the Art of Packing. Bentham coined the term 'Judge \& Co.' referred to in the title of this article.

2 3

This is a collection of essays which were originally delivered by distinguished jurists and lawyers from Australia and elsewhere at a highly successful conference to mark the retirement of Sir Anthony from the Court. The essays in the first part of the book serve as an extremely useful record of the achievements of the Court during this period.

4 Australian Capital Television Pty Ltd v the Commonwealth (1992) 177 CLR 106 ('ACTV case', as regards the freedom of communication); Chu Kheng $\operatorname{Lim} v$ Minister for Immigration and Ethnic Affairs 
s.92 (guarantee of freedom accorded to interstate trade) and s.117 (prohibition of discrimination on grounds of residence in other States). ${ }^{5}$ As well, there was a steady and decisive expansion of the rules of procedural justice (formerly known as 'natural justice') in the field of administrative law. This has been seen as a response to the previous increase in the range of powers and discretions vested in administrative agencies, resulting in the establishment of a 'unifying principle that decision makers whose decisions could cause loss of any kind should adopt fair procedures'. This was thought to be justified and appropriate as a proper check against oppressive government power' (Finklestein, 1996:62).

The developments on procedural justice included the controversial use made of international agreements as a means of enlivening the application of the same rules even though the agreements were not given the force of domestic law by the parliament.

Important changes occurred in the criminal law as regards the rights of defendants (for example, to legal representation in serious criminal trials); doctrines of estoppel; and unjust enrichment and restitution. It has been said that those changes illustrated the concern of the Court with the concepts of fairness or fair dealing or reasonableness in the relationships of citizen to government and citizen to citizen. An underlying view of reasonableness showed itself also in the trend towards making all cases in tort depend on intention or negligence (Jackson, 1996:24); Priestley, 1996:99-100). This involved the reversal of a number of long-standing cases including a case which had stood for 126 years in favour of strict liability for the escape of dangerous things.

An important contribution made by the Mason Court to the development of other areas of the law which govern dealings as between citizens was the treatment of fair dealing and good faith. This was illustrated by the increasing application of equitable doctrines to contracts and commercial law (see Renard, 1996). The beginnings of these developments pre-dated the period under review and were also accompanied

(1992) 176 CLR 1, 27 (protection from arbitrary arrest because of the inability of the parliament to vest judicial power in non-judicial bodies).

${ }^{5}$ Cole $v$ Whitfield (1988) 165 CLR 360 (s.92) and Street v Queensland Bar Association (1989) 168 CLR 461 (s.117).

${ }^{6}$ For example, Annetts v McCann (1990) 170 CLR 596; Ainsworth v Criminal Justice Commission (1992) 175 CLR 564.

Minister for Immigration and Ethnic Affairs $v$ Teoh (1995) 183 CLR 273. The case is seen by some as undermining the important democratic principle that the executive branch of government should not usurp the role of the elected representatives of the people in altering the law of the land. But see Walker (1996) and Evans (1996).

Dietrich v The Queen (1992) 177 CLR 292 (criminal law); Commonwealth v Verwayen (1990) 170 CLR 394 (estoppel); David Securities Pty Ltd v Commonwealth Bank of Australia (1992) 175 CLR 353 (unjust enrichment). See also Jackson (1996:23-4).

9

Bumie Port Authority v General Jones Pty Ltd (1994) 179 CLR 520 ovemuling Rylands v Fetcher (1868) LR $3 \mathrm{HL} 330$ which was said to by Mr Jackson (1996:24) to have fallen under the 'steamroller of negligence'. 
by legislative changes (such as the enactment of the Trade Practices Act and corresponding State and Territory legislation) which gave the courts greater powers to grant remedies against unfair dealings, especially in the field of consumer transactions, while apparently falling short of adopting the American concept of good faith as an essential element of the law of contract.

Australian courts have historically enjoyed the jurisdiction possessed by the English Court of Chancery to set aside contracts on the grounds of fraud, misrepresentation, breach of fiduciary duty, undue influence and unconscionable conduct. However, what made the application noteworthy under the Mason Court was the greater willingness of the courts to exercise the jurisdiction and to continue to develop the doctrines which regulate its exercise. This had a very significant impact on the law of contract. The High Court's approach to unconscionable conduct has been to prevent the enforcement of contractual bargains where this would lead to an unfair or unconscionable result. It has also enabled the courts to enforce the promises or reasonable expectations of parties to a commercial transaction, notwithstanding any technical difficulties which might otherwise have prevented this taking place.

These developments prompt some reflections on the era under discussion and the state of judicial law-making by the time Sir Anthony Mason retired from the Court.

\section{Achievements of the Mason Court}

By the time Sir Anthony Mason became Chief Justice, the process of ending appeals to the Privy Council had been completed as a result of the Australia Acts 1986, as had the establishment of the mechanism which ensures that all appeals heard by the High Court now lie in the discretion of the Court. That said, it is difficult to avoid the impression that the Mason Court favoured a degree of judicial activism. Many of the developments which occurred bear the hallmarks of Sir Anthony Mason's judicial philosophy (which itself underwent considerable change during his long period in office as a judge)." Sir Anthony rarely found himself in dissent.

A progressive attitude. The Mason Court was progressive at a time of great and accelerating social and economic change (Saunders, 1996:2). Its willingness to embrace technological change is illustrated by its decision in McKinney $v$ The Queen when the majority changed the rules relating to the admissibility in criminal trials of confessions

\footnotetext{
${ }^{10}$ A leading illustration of the latter development was the relaxation of the rules relating to consideration and privity of contract as essential requirements for the enforcement of a contract: Waltons Stores (Interstate) Ltd v Maher (1988) 164 CLR 387; Trident General Insurance Co Ltd v McNiece Bros Pty Ltd (1988) I65 CLR 107.

11

The less activist approach which he formerly supported is illustrated by the cases decided in the carly 1980s, discussed by the Chief Justice of the South Australian Supreme Court, John Doyle (1996:90-1); see also Kirby (1996). The change may perhaps be attributed to a heightened disillusionment with the effectiveness of the legislative process as a means of effecting necessary changes in the law.
} 
obtained from persons under interrogation while in police custody, by treating them as unsafe if they were not recorded on videotape. ${ }^{12}$ The same willingness to respond to changes in community perceptions is illustrated by $R v L$ when it was boldly asserted that, if it ever was part of the common law that marriage constituted continuing consent to sexual intercourse, it was no longer so in modern times. ${ }^{13}$ Yet the Court failed to embrace the new approaches to the rules of private international law recommended by Law Reform Commissions and academic writers. Significantly, this was one the few areas where Mason CJ lacked the necessary support of the rest of the Court for departing from the traditionally accepted rules.

An accessible style. The Mason Court abandoned the 'formalistic' and 'legalistic' style of judicial reasoning in favour of a more accessible style, even if this runs the risk of exposing the Court to greater criticism when it relies on policy considerations which are no longer hidden by the veil of legalism. This development seems to indicate that the Court might now have accepted the suggestion made long ago, namely, that 'the ground rules for principled (judicial) decision-making are exactly the same as those for the intelligent discussion of any issue' (Evans, 1976:68).

An Australian approach. The Mason Court is thought to have developed a distinctly Australian approach to its development of the law. The heavy if not exclusive reliance on English sources of law has now given way to a more varied willingness to consider sources of law in other countries for non-binding guidance and assistance. The development began before the elevation of Sir Anthony as Chief Justice and represents the achievement of a kind of national maturity which is the delayed but inevitable result of the formal attainment of Australian political and judicial independence.

Protecting the individual. For the author, perhaps the most important aspect of the Court's work during this period has been its concern for protecting the individual against the abuse of private and public power. ${ }^{15}$ Sir Anthony Mason and the Court as a whole obviously felt that the Court has a very significant and appropriate role to play in dealing with the rights of individuals: a role that does not necessarily presuppose the existence of a judicially enforceable Bill of Rights. His Honour had suggested that the

12

(1991) 171 CLR 468.

13

(1991) 174 CLR 379. A more recent, if not even more striking, illustration of the dynamic view taken of the nature of the common law resulted from the need to bring the law of defamation into conformity with the Constitution (and in particular the implied freedom of political communication). This was achieved by the reformulation of the common law defence of qualified privilege in Lange $v$ Australian Broadcasting Corporation (1997) 71 AIJR 818 ('Lange case').

14

Although it was unnecessary for the decision, Brennan, Dawson, Toohey and McHugh JJ reaffirmed the need to establish liability for interstate torts according to both the law of the place where the alleged wrongful act occurred and the law of forum in McKain v R W Miller \& Co (SA) Ply Ld (1991) 174 CLR 1. This was so despite the Court's decision in the earlier case of Breavington $v$ Godleman (1988) 169 CLR 41 where his Honour elaborated his support for the preferable and less mechanistic 'proper law' approach.

${ }^{15}$ For further discussion, see Finn (1996). 
degree to which a decision was 'determinative of the rights or interests of an individual' was a leading criterion for determining whether a decision should be the subject of judicial review (Mason, 1989:124).

Equitable rules. So far as private law is concerned, it is questionable whether the courts should extend the reach of equitable rules in relation to commercial transactions where the parties can be expected to have access to legal advice and enjoy equal bargaining power, leaving aside the transactions which involve small business and consumers. ${ }^{16}$ There is the further need to strike an appropriate balance between faimess, on the one hand, and on the other, certainty and predictability in commercial transactions. Some will also question the ability, as well as the need, for judges to fix standards in the market place for such parties. They will ask why the same parties should as a rule be able to use a valuable public resource - the court system - to arbitrate their commercial disputes.

Public law. In the field of public law, the Mason Court become increasingly occupied with restrictions on legislative power which are not concerned with the federal nature of the Constitution. As a former Commonwealth Solicitor-General, Sir Maurice Byers QC, observed, if anything characterised the Mason Court it was the implicit rejection of an aspect of the landmark decision in the Engineers case ${ }^{17}$ which strongly affirmed that the ballot box was the only answer to potential abuse of power exercised by the majority in parliament. This is consistent with Sir Anthony Mason's view that 'our evolving concept of the democratic process' was 'moving beyond an exclusive emphasis on parliamentary supremacy and majority will' and as embracing 'a notion of responsible government which respect(ed) the fundamental rights and dignity of the individual...' (Mason, 1987:163).

Mabo. The Mabo case raises interesting parallels with the landmark decision of the US Supreme Court in Brown $v$ Board of Education regarding the desegregation of public schools. ${ }^{18}$ The protection accorded to native title consists of the inability of the Commonwealth to legislate for the acquisition of native title without the provision of 'just terms' (that is, compensation), and also the inability of the States to legislate in respect of native title otherwise than in accordance with the terms of the Racial Discrimination Act 1975 (Cth) and Native Title Act 1993 (Cth) by reason of s.109 of the Constitution.

One rationale that is sometimes advanced for the developments which began with Brown v Board of Education and culminated in the activism of the Warren Court in the United States in the 1960s is that the court should intervene to protect individuals

\footnotetext{
${ }^{16}$ See the discussion in Renard (1996:71-80). The leading exponent and supporter for increasing the reach of equitable doctrines in commercial transactions which do not necessarily involve consumers or parties that are not in an unequal bargaining position, has been Mr Justice Paul Finn, a judge of the Federal Court: see Finn (1989).

17 18

Amalgamated Society of Engineers $v$ The Adelaide Steamship Co. Ltd (1920) 28 CLR 129 at 152 (1954) 347 US 483.
} 
and groups who are denied real access to the political process. Perhaps a similar explanation can be advanced in relation to the High Court's solution to the native title question. The pursuit of this approach does achieve very valuable results at least in the short term and the decision of the Court in Mabo certainly did have the effect of breaking a difficult political and legislative log-jam on the Aboriginal land rights question. But to adopt, in the words of Mr Jackson QC (1996:25), 'reasoning' which 'did not follow earlier perceptions of the effect of European settlement' comes at a considerable cost, as is illustrated by the torrent of virulent criticism unleashed against its decision in that case and also the even more virulent (but with far less justification) criticism unleashed against the succeeding case in Wik. ${ }^{19}$ The fact that, as Sir Anthony Mason (1996:114) observed, the Australian High Court did for the indigenous inhabitants of Australia only what the courts in the United States, New Zealand and Canada did for their indigenous peoples is unlikely to calm the voice of the critics in Australia. The adoption of the rationale adverted to above also has the potential to make the courts a potential dumping ground for issues which are too hot for politicians to handle. $^{20}$ In the author's view, it is extremely doubtful whether courts should act to upset traditional understandings of the law in advance of public opinion or where significant sections of the community are divided on the need for a change in the law.

Section 92. The praise accorded to the decision in Cole $v$ Whitfield is well deserved (Zines, 1995). The case adopts an interpretation which probably and more closely reflects the intentions of the framers when they resolved to provide that 'trade, commerce, and intercourse among the states ... shall be absolutely free' in s.92 of the Constitution. This was done in a unanimous judgment, 'the most important parts' of which were said, by the present Chief Justice, to have been written by Sir Anthony Mason (Brennan, 1996a:13). In that judgment the Court adopted a free-trade (federal) approach to the interpretation of that section (aimed at the elimination of protectionism in a common market). This had the effect of abandoning the misplaced laissez faire view of the section which had prevailed since the Bank Nationalisation case was decided in 1949 when legislation to nationalise private banking was held to violate $s .92$ despite the absence of any suggestion that the legislation discriminated against interstate banking. The Court was able to clarify the interpretation of one of the most litigated sections of the Constitution even if the unanimity of the Court was disturbed shortly afterwards in the application of the new test in relation to the taxation of interstate trade and commerce. As Emeritus Professor Zines (1995:18) correctly points out, the effect of the new test will be to increase the scope of both Commonwealth and State power to regulate and control trade and commerce. If

\footnotetext{
${ }^{19}$ Wik Peoples v Queensland (1996) 71 ALJR 173. 20

Adapted from the language used in Sturgess and Chubb (1988:123), who, however, refer to the tendency of modern legislatures to leave certain issues to be determined by the courts as a reason for justifying judicial creativity.

21

The Commonwealth v Bank of New South Wales (1949) 79 CLR 497.

Bath v Alston Holdings Pty Ldd (1988) 165 CLR 411.
} 
so, it will not be the first time that the Court has interpreted the Constitution in a way that expands governmental power at a time when the governments then in office show the least signs of exercising that power. This occurred, for example, with the effect of the Engineers' case on the scope of the Commonwealth's legislative powers. The conservative Bruce Government showed little interest in realising the full potential of those powers during the 1920s (Sawer, 1956:329; Zines, 1992a:75-6). The same can obviously be said about the ability of governments to nationalise banks and other forms of trade and commerce at the present time. But the Court's new approach will at least have the effect of restricting the destructive potential of $s .92$ to invalidate legislation which deals with the control and taxation of trade and commerce including such matters as the marketing of primary products and transportation of goods and persons.

Professor Zines (1995) has rightly praised the Court's tendency to prefer substance over form in its new-found willingness to give greater effect to constitutional restrictions on legislative power (such as s.117 of the Constitution). The earlier tendency to give restrictions on power a restrictive, narrow and formal operation was probably symptomatic of the lingering influence of the British doctrine of parliamentary supremacy.

The Court's willingness to depart from the previous interpretations of $s .92$ was not matched by its reluctance to disturb the wide view taken of the meaning of excise in 5.90 under which the States are excluded from imposing a wide range of taxes on the production, manufacture and distribution of goods. But this may be due to the policy predilections of the majority who viewed the purpose of $s .90$ as helping to 'create a Commonwealth economic union and not an association of States each with its own separate economy'. ${ }^{23}$ A majority of the present Court subsequently adhered to the wide view of excise but in a way that destroyed the practical significance of certain kinds of franchise fees on tobacco and liquor which the States had previously been able to levy under an anomalous exception to the wide view.

Implied rights. The $A C T V$ case has attracted much popular interest at least for the result it achieved in recognising the existence of some kind of constitutional guarantee of the freedom of political communication which restricts legislative power and is implied as an indispensable element of the representative democracy that is recognised in the Australian Constitution. Perhaps one of the reasons for its general popularity was its attractiveness to the media for the effect it had, as a result of subsequent decisions, in 'reforming,' on a uniform basis throughout Australia, the law on defamation so to facilitate the discussion of political matters. ${ }^{25}$ Attempts to achieve reform in

${ }^{23}$ Capital Duplicators Pty Ltd v Australian Capital Territory /No 2J (1993) 178 CLR 561 at 585 per Mason CJ, Brennan, Deane and McHugh JJ. Dawson, Toohey and Gaudron JJ dissented.

${ }^{24}$ Ha $v$ New South Wales (1997) 71 ALJR 1080 per Brennan, McHugh, Gummow and Kirby Jj; Dawson, Toohey and Gaudron JJ dissenting.

25

Theophanous v Herald and Weekly Times LAd (1994) 182 CLR 104; Stephens v West Australian Newspapers Ldd (1994) 182 CLR 211. 
this area by means of cooperation between Australian government and parliaments have proved to be singularly unsuccessful.

More recently, in the Lange case the Mason Court decisions on defamation were accepted as authority for deciding that the law on defamation as previously interpreted failed to conform with the freedom in question. But the law was brought into conformity with the Constitution in a different way from that suggested by the earlier decisions, although this seems to have produced substantially similar results to those achieved in the earlier defamation cases even if those results do not stem directly from the operation of the constitutional freedom.

What has concerned some legal commentators is not the utility of the results described above but rather the judicial vehicle used to bring them about. Judicial implications from the structure of the Constitution, for example in relation to federalism and the separation of judicial from legislative and executive powers, are not new. What was new about the process of implying restrictions on legislative power from the representative nature of the governmental institutions created by the Constitution was the fact that such implications had the potential to defeat the acknowledged intentions of the framers of the Australian Constitution not to adopt a Bill of Rights. The orthodox understanding was that in that respect Australia remained more closely aligned with British notions of constitutional law, under which as Dawson J was to point out 'the guarantee of fundamental freedoms' did not lie in 'any constitutional mandate but in the capacity of a democratic society to preserve for itself its own shared values'. This gives rise to serious doubts about whether the judges enjoy a democratic mandate to give effect to an implied Bill of Rights, as well as the usual concerns about the use of implications as a vehicle for judges giving expression to their own subjective values.

Some of these concerns may be alleviated by Sir Anthony Mason's acknowledgment that in view of the decision of the framers to eschew the American model of a Bill of Rights it is difficult if not impossible to establish a foundation for the implication of general guarantees of fundamental rights and freedoms. ${ }^{28}$ The implication he supported was confined to strengthening the workings of representative democracy. This would help to perfect the integrity of the process by which decisions are made rather than determine the outcomes which emerge from that process.

Not all judges were or would be content to limit the process of implication in this way. Quite apart from the inherent potential of a freedom of political communication to embrace other important freedoms such as freedom of movement, association and assembly, ${ }^{29}$ the concept of representative democracy might be seen to extend to other

${ }^{26}$ Lange case (1997) 71 AIJR 818. But the present Court failed to confirm the application of the constitutional freedom to discuss political matters which are not relevant to the federal level of government.

27 ${ }^{28}$ Ibid at 136.

${ }^{29}$ As Professor Zines (1991:34-5) has indicated, 'provisions concerned with the establishment and maintenance of democratic processes appear, to some degree, to shade into those which are thought 
basic rights which are not restricted to ensuring the genuine and effective nature of the election process. As well, some judges have in the past suggested that equality is necessarily implied from the Constitution even though the framers explicitly refused to include this right in the Constitution: which is true also of the implied constitutional inability of the Commonwealth parliament to create retrospective criminal offence. ${ }^{30}$

Admittedly, the chances of a majority accepting the implication of equality seem greatly diminished given the Court's rejection in the recent case which involved the removal of Aboriginal children from their families. ${ }^{31}$ Moreover, a majority of the Bench as presently composed seems to be opposed to the use of general concepts such as representative democracy as free-standing principles which operate independently of those provisions, when those concepts are only partially recognised in the express provisions of the Constitution; that is, as a reason for invalidating legislation which does not otherwise breach the express provisions of the Constitution. Reference has already been made to the decisions of the present Court which may be taken to have consolidated rather than extended previous developments; but generalisations can be hazardous given the surprising case of Kable $v$ Director of Public Prosecutions $(N S W)^{33}$ where a majority of the Court has begun to extend some aspects of the separation of judicial powers case into the State judicial sphere.

\section{Concluding Remarks}

It has been said that the end of the Mason Court era coincided with a vigorous debate about the limits of judicial creativity in Australia. It was also said that the debate clearly reflected the reputation earned by the Mason Court especially during the latter part of the former Chief Justice's tenure as a court of final jurisdiction which gave effect to a conscious philosophy of judicial activism (Sackville, 1997:145-6). Many leading members of the Australian judiciary have acknowledged that judges make law as a result of the inevitable choices which confront them in the decision-making process (see

desirable by people who emphasise, not merely democratic structures, but liberty of the individual and the protection of the individual'.

30

Although the suggestion in relation to equality was supported for different reasons by Brennan, Deane, Toohey and Gaudron IJ in Leeth $v$ The Commonwealth (1992) 174 CLR 455, the case has not been taken as establishing its correctness. The same can be said in regard to the support expressed by Deane, Toohey and Gaudron JJ in Polyukhovich v The Commonwealth (1991) 172 CLR 501 as regards the suggestion in relation to retrospective criminal offences. Both cases are discussed in Zines (1997:418-20 and 210-12, respectively) and Lindell (1994:33-7).

31

Kruger $v$ The Commonwealth (1997) 71 ALJR 991 per Brennan CJ, Dawson, Gaudron, McHugh and Gummow; Toohey $\mathrm{J}$ dissenting. Three of the majority judges rejected the implication without qualification but Brennan CJ's remarks can be confined to laws for the Territories enacted under s.122 and GaudronJ supported a limited constitutional guarantee of equality.

32 33

Lange case (1997) 71 AIJR 818 at 830.

(1996) 70 AIJR 814 where a majority of the Court held invalid State laws which provided for the judicial authorisation of the preventative detention of persons who were thought to pose a threat to the lives of others (Toohey, Gaudron, McHugh and Gummow JJ: Brennan CJ and Dawson J dissenting). 
for example Doyle, 1996; Sackville, 1997; Kirby, 1983). The present Chief Justice of the High Court said:

In modern times the function of the courts in developing the common law has been freely acknowledged. The reluctance of the courts in earlier times to acknowledge that function was due in part to the theory that it was the exclusive function of the legislature to keep the law in a serviceable state. But legislatures have disappointed the theorists and the courts have been left with a substantial part of the responsibility for keeping the law in a serviceable state, a function which calls for consideration of the contemporary values of the community.

The notion of ensuring that the law is kept in a 'serviceable state' is particularly applicable to what might be termed 'lawyers law' in the areas of law such as torts and contracts. Parliaments may well assume that the courts will develop in an orderly manner the law in those areas safe in the knowledge that any unwanted results of that development can if necessary be reversed by overriding legislation. The assumption here is also that courts do not change the law on matters which divide the community. Even in the area of 'lawyer's law,' however, it is important for the courts to develop techniques to ensure that the expectations of persons who plan their affairs in reliance on previous case law are not defeated. The difficulty with the judicial acknowledgment of law-making by judges is, however, that, as Professor Brian Galligan has correctly pointed out, the judiciary may have failed to prepare the public for that acknowledgment. ${ }^{33}$ Public understanding would not be assisted by the acceptance of a literal and oversimplified version of the doctrine of the separation of powers.

Sir Gerard Brennan has attempted to confine the acknowledgment of judicial lawmaking to the development of the common law (as distinct from the interpretation of the Constitution) ${ }^{36}$ and also to stress, as others have, that judges make law in a very different way from that of the political branches of the government. He emphasised that 'the development of the substantive principles of law by the High Court must be the outcome of the application of the judicial method to the cases that come before it' (Brennan, 1996b:264; emphasis added).

The attempt to confine the acknowledgment of judicial law-making to the development of the common law and so deny its application to the interpretation of the Constitution is curious. While undoubtedly deriving some theoretical support from democratic considerations, it will be difficult in practice for a court not 'to make law' and thus have regard to policy considerations, in any area of the law including constitutional law, at least when those consideration are used in the same special and con-

\footnotetext{
34 35 36

Dietrich v The Queen (1992) 177 CLR 292 at 319 per Brennan J as he was then. Theophanous v Herald and Weckly Times Ltd (1994) 182 CLR 104 at 143.
} 
fined sense that will be explained below. This is because of the necessary brevity and open nature of constitutional provisions which call for interpretation.

Sir Gerard Brennan's attempt to emphasise the use of the 'judicial method' is more persuasive. For him, the scope of judicial policy, as distinct from political policy, is informed by precedent and disciplined by analogy; and these factors confine the scope for discretionary judgement (Brennan, 1996a:13). Sir Anthony Mason stressed the place of the strong traditions of consistency, coherence and continuity in the orderly development of the law. Judicial decision-making was seen as principled and reasoned, in contrast to political decision-making which involves compromise and expediency. Moreover, the need to resolve disputes between the parties before the court necessitates closer attention to the interests of individuals since it is concerned with the particular, whereas political decision-making is much more concerned with the general. The differences also go to procedure and method in that judges are bound to hear the interested parties and give public reasons for their decisions. They are also required to deal with problems raised by litigants while politicians are free to decline to deal with problems raised for their decision (Sturgess \& Chubb, 1988:3467).

A final factor is that courts can decide only the cases that come before them and cannot on their own initiative decide issues in the absence of litigation which involves their determination. As well, in Australia the ability of federal courts to render advisory opinions is restricted. The significance of these factors should not be exaggerated since, as a final court of appeal, the High Court has a high degree of control over the cases which it chooses to hear under the special leave process. In addition judges can signal their interest in certain issues in a way that may encourage legal advisers to recommend the initiation of litigation which will raise those issues. Some constitutional cases also have a suspicious similarity with advisory opinions, given the willingness of the High Court to entertain in some cases challenges to the validity of legislation before it comes into force.

If judicial law-making is now accepted by judges of Australian courts, or at least those at the appellate level, some difficult issues remain regarding the way this role is to be performed in the future, as was clearly demonstrated by Doyle CJ (1996) of the South Australian Supreme Court. His Honour believed that the work of the Mason Court would come to be regarded as marking a significant development in Australian legal thinking and judicial techniques. It has prepared Australian courts for a new approach to their law-making function. But awaiting its successors were the tasks of defining more clearly the limits between the law-making role of the Courts and that of parliament; clarifying and expounding the judicial techniques which support the lawmaking function; and refining the procedures of the Court to enable the function to be carried out in the best possible way. The warnings are timely and he is not the only judge to have issued them (see for example Sackville, 1997).

\footnotetext{
${ }^{37}$ For a typical example see Zines (1992b:54-9) on how it is almost impossible for judges not to have regard to functional considerations in determining the characterisation of laws in the distribution of powers between the Commonwealth and the States.
} 
In relation to the function of courts to keep 'the law in a serviceable state', Chief Justice Doyle (1996:93-4) has pointed to the significant distinction between the need for changes generally and the need for those changes to be brought about by judicial action. Searching questions are raised as to whether the reasons given by the High Court in such cases as Mabo sufficiently addressed that distinction. This was so in the latter case despite the fact that it is seen by some as coming very close to the boundary between the appropriate roles of the legislature and the judiciary' (Jackson, 1996:25) and also that the practical impact of the decision was such that an urgent legislative response was required since it was widely agreed that the impact of the decision could not be left to be sorted out in accordance with common law principles on a case-bycase basis. The legislation in question was to have very significant political, social and economic consequences (Doyle, 1996:93).

The procedures adopted by the Court to carry out its law-making function will need to address the tendency of judges in the modern era to resort to community values and perceptions as a reason for changing the law. They will also need to address the associated need for more systematic materials to be placed before the courts in relation to such matters. Changed social, political and economic conditions are legitimate factors which call for changing judge-made law. Yet the use made of such values is obviously not free from danger, especially as some judges could smuggle their own subjective values under the guise of perceived community standards, and arriving at the commonality of such values is difficult in an increasingly multicultural society. Sir Anthony Mason is probably right to reject any calls for the introduction of surveys to gauge contemporary values (1996:114); but Doyle CJ (1996:96-7) is surely right to insist on more systematic materials being placed before the Court for this purpose.

In a recent case the Court may have failed to keep the law up to date when it refused to accept the right of patients to obtain copies of their medical records despite Canadian judicial developments which affirmed the existence of such a right, ${ }^{38}$ and despite the acknowledgment by two members of the Court that a majority of the community would support such a right. ${ }^{3}$ A liberal approach may also need to be adopted in relation to the exercise of the power to allow for the intervention of third parties. ${ }^{40}$ Another technique which deserves greater attention is the possibility of a court engaging in prospective overruling so as to ensure that when previous cases are overruled the effects of the establishment of any new rules are confined to the future and to the immediate parties in the litigation which gives rise to the new rules. Its full acceptance probably calls for the demise of the lingering remnants of the declaratory theory of law. The technique, however, seemed to receive short shrift in the recent $\mathrm{Ha}$ case on s.90 where it was rejected by both the majority and the minority on the ground that prospective overnuling was inconsistent with the exercise of judicial

\footnotetext{
38

Breen v Williams (1996) 70 ALJR 772. See also Sackville (1997:159).

Gaudron and McHugh IJ at (1996) 70 ALJR at $794-5$.

40

The existing law on the matter was discussed by both Brennan CJ and Kirby J in Levy v Victoria (1997) 71 AlJR 837 at $843-6,873-4$ respectively.
} 
power, $^{41}$ despite the absence of any discussion of the tentative steps that may have been taken in that direction before the decision of the Court in the Ha case.

In 1921, a famous American judge, Benjamin Cardozo, lucidly analysed the question of judicial law-making in a way that fully and freely accepted its existence. But he accepted that for practical reasons, if nothing else, adherence to precedent should be the rule and not the exception. Cardozo (1978:112-13) summarised the process of judicial law-making as requiring courts to have regard to four factors: (i) logical progression (mainly inductive rather than deductive as involving law-making by analogy); (ii) historical development and evolution; (iii) the customs, morals and traditions (including the accepted standards of 'right' conduct) of a society; and (iv) social utility or welfare. Courts and the legal community generally have yet to improve on this test in elaborating the limits of judicial law-making.

The challenge for the modern judge remains, in the words of Justice Michael Kirby (1997:11), to 'find where the line lies in a particular case, at a particular time and place'. As indicated by Professor Saunders (1996:8), the most significant issue for the judiciary here and around the world 'is the difficult and delicate task of finding an appropriate balance between the functions of the courts and the other arms of government' particularly in age 'in which the assumptions of majoritarian representative democracy have been eroded from both inside and out without the full ramifications of the change being , as yet, fully explored or understood'. That said, '(t)he legacy of the Mason Court is a useful base from which to start' to resolve such issues.

\section{References}

Brennan, G. (1996a), 'A Tribute to Sir Anthony Mason', pp. 10-14 in C. Saunders (ed.), Courts of Final Jurisdiction: The Mason Court in Australia, Federation Press, Sydney.

(1996b), 'Looking to the Future', pp. 2648 in C. Saunders (ed.), Courts of Final Jurisdiction: The Mason Court in Australia, Federation Press, Sydney.

Cardozo, B. (1978), The Nature of the Judicial Process, Yale University Press, New Haven.

Constitutional Conmission (1988), Final Report, Vol. 1, AGPS, Canberra.

Doyle, J. (1996), 'Implications of Judicial Law-Making', pp. 84-98 in C. Saunders (ed.), Courts of Final Jurisdiction: The Mason Court in Australia, Federation Press, Sydney.

Evans, G. (1976), 'The Most Dangerous Branch? The High Court and the Constitution in a Changing Society', pp. 13-76, 113-17 in D. Hambly \& J. Goldring (eds), Australian Lawyers and Social Change, Law Book Co., Sydney.

(1996), 'The Impact of Internationalisation of Australian Law: A Commentary', pp. 236-41 in C. Saunders (ed.), Courts of Final Jurisdiction: The Mason Court in Australia, Federation Press, Sydney.

Finklestein, R. (1996), 'Procedural Faimess', pp. 47-62 in C. Saunders (ed.), Courts of Füal Jurisdiction: The Mason Court in Australia, Federation Press, Sydney.

\footnotetext{
41

(1997) 71 ALJR 1080, at 1093 and 1099-1100.

Bropho v Western Australia (1990)171 CLR 1 (but note the refusal in that case to adopt the technique by Brennan $J$ as he was then); McKinney $v$ The Queen (1991) 171 CLR 468. See also Sackville (1997:159); Keith Mason (1989); Constitutional Commission (1988:424-5).
} 
Finn, P. (1989), 'Commerce, the Common Law and Morality', Melboume University Law Review 17: 87. 106.

(1996), 'Controlling the Exercise of Power', Public Law Review 7: 86-95.

Jackson, D. (1996), 'The Role of the Chief Justice: A View from the Bar', pp. 21-7 in C. Saunders (ed.), Courts of Funal Jurisdiction: The Mason Court in Australia, Federation Press, Sydney.

Kirby, Justice M. (1983), The Judges, ABC, Sydney (Boyer Lecture Series).

(1996), 'A.F. Mason - From Trigwell to Teolh, Melboune University Law Review 20: 1087-107 (Sir Anthony Mason Lecture).

— (1997), 'Judicial Activism', Bar Association of India Lecture delivered in New Delhi on 6 January [http://www.hcourtgov.au/indialthtm].

Lindell, G. (1994), 'Recent Developments in the Judicial Interpretation of the Australian Constitution', pp. 1-46 in G. Lindell (ed.), Future Directions in Australian Constitutional Law, Federation Press, Sydney.

Mason, A. (1987), 'Future Directions in Australian Law', Monash Law Review 13: 149-63.

(1989), 'Administrative Review - The Experience of the First Twelve Years', Federal Law Review 18: 122-33.

(1996), 'A Reply', pp. 113-16 in C. Saunders (ed.), Courts of Final Jurisdiction: The Mason Court in Australiz, Federation Press, Sydney.

Mason, K.(1989), 'Prospective Overnuling', Australian Law Joumal 63: 526-31.

Priestley, L. (1996), 'Influences on Judicial Law-Making', pp. 99-106 in C. Saunders (ed.), Courts of Final Jurisdiction: The Mason Court in Australia, Federation Press, Sydney.

Reid, L ord J. (1972), 'The Judge as Lawmaker', Joumal of Public Teachers of Law 12: $22-9$.

Renard, I. (1996), 'Fair Dealing and Good Faith' pp. 63-83 in C. Saunders (ed.), Courts of Final Jurisdiction: The Mason Court in Australia, Federation Press, Sydney.

Sackville, R. (1997), 'Continuity and Judicial Creativity - Some Observations', University of New South Wales Law Journal 20: 145-69.

Saunders, C. (1996), 'The Mason Court in Context', pp. 2-8 in C. Saunders (ed.), Courts of Final Jurisdiction: The Mason Court in Australia, Federation Press, Sydney.

Sawer, G. (1956), Australian Federal Politics and Law 1901-1929, Melbourne University Press, Melbourne.

Sturgess, G. \& P. Chubb (1988), Judging The World: Law and Politics in the World's Leading Courts, Butterworths, Sydney.

Walker, K. (1996), 'Treaties and the Internationalisation of Australian Law', pp. 204-35 in C. Saunders (ed.), Courts of Final Jurisdiction: The Mason Court in Australia, Federation Press, Sydney.

Zines, $\mathrm{L}$. (1991), Constitutional Change in the Commonwealth, Cambridge University Press, Cambridge. (1992a), 'The Commonwealth', pp. 71-100 in G. Craven (ed.), Australian Federation: Towards the Second Century, Melbourne University Press, Melbourne.

— (1992b), 'Characterisation of Commonwealth Laws', pp. $33-59$ in H.P. Lee \& G. Winterton (eds), Australian Constitutional Perspectives, Law Book Co., Sydney.

- (1995), 'The Most Significant Case of the Mason High Court', Australian Lawyer 30: 18-21.

- (1997), The High Court and the Constitution (4th ed.), Butterworths, Sydney. 